\title{
7. The Role of Songs in Connecting the Living and the Dead: A Funeral Ceremony for Nakodjok in Western Arnhem Land
}

\author{
Reuben Brown
}

\section{Prologue: Nakodjok returns}

The family had waited a long time for this. Their father had passed away some six months earlier, in the middle of the wet season in the Top End of the Northern Territory, and his body had been held in a morgue in Katherine all this time. Now that the dry season had begun and the water levels along the rivers and flood plains had receded, some of the remote dirt roads through Arnhem Land were once again open. The family's outstation on their ancestral Country at Mikkinj Valley was now accessible via a road that ran east from the Aboriginal community of Gunbalanya (also known as Oenpelli), ${ }^{1}$ and then west around the other side of the Arnhem Land escarpment, and preparations to bury their father on his Country could begin in earnest. The burial had been planned for August, but with more deaths in the community of Gunbalanya creating a backlog of funerals and limiting space in the local morgue, the date was brought forward. In late June, the body of Nakodjok Nayinggul (or Nakodjok Namanilakarr, ${ }^{2}$ as he was referred to post-mortem) was finally returned to the family in a charter plane from Katherine to Gunbalanya.

\footnotetext{
1 Gunbalanya is the Kunwinjku name for the Aboriginal community formerly known (and still referred to by some) as Oenpelli. Oenpelli was first established as a buffalo-skinning camp in the early 1900s before it became a government cattle station and then a mission in 1925. Opportunities for work and rations drew various clans from the region to Oenpelli, reflected in the multilingual makeup of the population today.

2 Nakodjok means a male (Kunwinjku noun class prefix na-) belonging to the kodjok subsection (in the kinship system of western Arnhem Land), while Namanilakarr means a male of the Manilakarr clan group. Throughout this chapter, significant words that form part of the lexicon of western Arnhem Land songs in the Aboriginal languages of Kunwinjku (K) and Mawng (M) are indicated in italics (except proper nouns such as names of people and songs). English translations are glossed in brackets the first time the word appears in the text. I adopt standard orthographies for both Kunwinjku and Mawng. See Nicholas Evans, Bininj Gunwok: A pan-dialectal grammar of Mayali, Kunwinjku and Kune. 2 volumes (Canberra: Pacific Linguistics, 2003); Ruth Singer, Agreement in Mawng: Productive and lexicalised uses of agreement in an Australian language (PhD, Department of Linguistics and Applied Linguistics, University of Melbourne, 2006).
} 
Under instructions from the family, all work in the community finished for the day at 2:30 pm. Bininj and Balanda ${ }^{3}$ gathered outside the house where Nakodjok had lived during the last part of his life, waiting in the sweat-inducing afternoon sun. There in the front yard, Nakodjok used to sit in his wheelchair, smoking a cigarette, waiting to greet the next researcher to show them his Country, the next council worker to accompany him to a community meeting, or a family member who would wheel him over to the 'club' in the evening. Now the yard was occupied by his extended family, who sat with their children in the shade of tents. A tub of delek (K: white ochre mixed with water to form clay) was passed around for those who wished to paint their arms, legs, face and hair - a ritual that accompanies ceremonial song and dance in Bininj culture. At one end of the yard, further away from the tents, a visiting group from Ramingining sat under a tree singing, in part to keep their hosts - the family of Nakodjokcompany. I saw my chance to go inside and pay my respects to the family, and asked one of Nakodjok's grandchildren, 'Kamak bu ngam-re-ngimen?' ('Is it OK if I go inside?'). He gave me the sort of slightly quizzical look that I was now accustomed to receiving from younger Bininj who were not used to a Balanda addressing them in Kunwinjku. ${ }^{4}$ Then he replied, 'Mah, kamak' ('OK, that's fine'). He led me through the house into a dark bedroom, where I found Nakodjok's daughters sitting around the coffin, with their heads lowered and hands resting on the polished wood that encased their father.

One of Nakodjok's daughters, Connie Nayinggul, acknowledged me with a nod as I came in. Like many of Nakodjok's children, Connie took a leading role in the community, particularly around cultural matters. Like her father, she was generous about sharing Bininj knowledge with outsiders, and sought to bring the various elements of the Gunbalanya community together by including them in cultural practices, such as gathering, preparing and cooking food in the traditional way. Now she was covered in delek, and her hair had been teased into a frizz. Her voice was hoarse from an earlier display of public grief at the airstrip in Gunbalanya upon the return of Nakodjok's body. She spoke quietly and determinedly, informing me of the funeral arrangements, and asking if I could pass on the invitation to some other Balanda researchers who had worked with Nakodjok in recent times. She pointed out Nakodjok's black cowboy hat hanging proudly on the wall. Once a symbol of his affiliation with stockmen, ${ }^{5}$ it

\footnotetext{
3 'Bininj' means Aboriginal person, while the Macassan loan word 'Balanda' (from 'Hollander') refers to a non-Aboriginal person or European. The second meaning of bininj (italicised, no capitals) is 'male', as opposed to daluk (female).

4 Kunwinjku is one of six dialects in western Arnhem Land referred to collectively as Bininj Gun-wok ('Aboriginal people's language'). It is the main language spoken at Gunbalanya and is also spoken in other communities of western Arnhem Land. Evans, Bininj Gun-wok, 6.

5 Nakodjok's family and other traditional owners of Gunbalanya helped establish a locally owned meatworks where the cattle that graze on the floodplains of Gunbalanya are slaughtered, processed and packaged for delivery all around the region.
} 
had now become a sort of cult fashion item among the grandchildren, who wore their own hats as a sign of respect for Nakodjok. Connie then pointed out a gold plate at the head of the coffin, etched with Nakodjok's name. To an outsider, this detail, along with the large framed photograph of Nakodjok wearing his iconic hat that was later displayed during the funeral service at Gunbalanya church, seemed to sit awkwardly with the Bininj practice of avoiding the name, image or other aspects of the deceased during the period of mourning. Yet it also indicated the incorporation of Judaeo-Christian traditions by Bininj, ever since they had moved from the bush to live among the missionaries in the early twentieth century, the era into which Nakodjok was born. ${ }^{6}$

I said bobo (K: goodbye) to the daughters and stepped back outside into the blinding sun. Soon the bininj (K: men) went inside the house to collect the coffin. This was when the local group of singers started to perform their Karrbarda (K: long yam) songs, starting as all western Arnhem Land songs do, with the blowing of the mako (K: didjeridu). Then came the fast beating of the clapsticks, providing the tempo for the didjeridu and a cue for the men to begin dancing. The 'dance captain'7 of the group, Joey Nganjmirra, took off his shirt and wrapped it around each fist, pulling it tight in the middle. The men came together for the opening dance call, a shouting 'oh, argh', slapping their thighs twice before pointing their fingers to the sky and calling 'yi!' At the end of the verse they danced toward the body and began the 'stamping phrase', lifting their knees high in the air and kicking up the sand with their feet to the beat of the clapstick, and pausing with the suspension of the beat. ${ }^{8}$ Accompanying each stamp, they gave a different dance call that sounded like a hiss, while Nganjmirra held the taut shirt out in front of him and rotated it at different angles to articulate the movement. Then the sound of the singing, didjeridu and clapsticks, and the flicking of sand was joined with a loud banging against the thin metal walls of the house, as the coffin was hoisted above the heads of the young men and taken out of the house away from the grieving daughters. Outside, other daluk (K: women) joined in the wailing and crying, and onlookers shouted directions at the coffin-bearers, helping to steer the coffin from the narrow entrance of the house towards the back of the 'troopy' ${ }^{9}$ that waited

\footnotetext{
6 The practice of displaying a photo of the deceased at the funeral service is also common among Yolngu of east Arnhem Land. See Jennifer Deger, 'Imprinting on the Heart: Photography and contemporary Yolngu mournings', Visual Anthropology 21 (2008): 292-309.

7 English term used by Eric Mardday to describe the leader of the male dancers for the Karrbarda song-set. Eric Mardday, interview with the author, September 2013.

8 The description of the 'stamping phrase' - one of the conventions of western Arnhem Land dance - is based on similar descriptions of wangga dance provided by Marett. Allan Marett, Songs, Dreamings, and Ghosts: The wangga of north Australia, (Middletown: Wesleyan University Press, 2005).

9 The Toyota Land Cruiser is a four-wheel-drive vehicle that can seat many passengers, ubiquitous throughout remote Aboriginal Australia, and commonly referred to as a 'troop carrier' or 'troopy'. In western Arnhem Land these mutika (vehicles) are used frequently for the transportation of deceased, after which they are ceremonially smoked and streaked with red ochre.
} 
in the yard. Some daluk held rocks above their heads, threatening to strike themselves in a gesture of their uncontrollable grief, before bininj intervened and restrained them. As the sounds of grief grew to a crescendo, I reflected how the emotion was at once real and well rehearsed, the actions both spontaneous and semi-staged.

Rising above the sounds of the bereaved, the Karrbarda singers slowed down the tempo of their clapstick beating and began singing a sweet melody, the notes of which were more elongated than before. Leading songman Eric Mardday kept singing, repeating another verse until the coffin had been securely placed inside the troopy and the rear doors swung shut. At this point, the wailing turned to sobbing, and the song came to a close. With emergency lights flashing, the vehicle slowly made its way out of the yard, around the corner and down the street to a small room at the back of the Gunbalanya health clinic known as the 'morgue house'. The family stayed close to the troopy while the rest of us followed behind in quiet reflection. Once more the Ramingining mob took over, singing Nakodjok's coffin out of the troopy and into the morgue. Connie then addressed everyone, thanking them for coming and confirming plans for a memorial service in Gunbalanya, followed by a burial ceremony out at Mikkinj Valley outstation in three weeks' time. 'Mah, bonj' she said ('Ok, that's it'). It was decided.

\section{Introduction}

This description of the movement of the deceased from his family home to the local morgue - reconstructed from field notes I took in Gunbalanya in western Arnhem Land in 2012 - relates to just one of the many stages of the burial of Nakodjok involving song and dance. Each of these stages marked an aspect of the deceased's transition, both in terms of the body and the spirit. In this chapter I show how song and dance express and mediate relationships between Aboriginal people, both living and deceased. Taking as a case study Nakodjok's funeral ceremony, which began in the community of Gunbalanya and ended at his outstation at Mikkinj Valley, I trace the diverse range of songs that were performed at various stages of transition. By attending the funeral ceremony and performing songs for the families of the deceased, Bininj and other Aboriginal people from around the region show their respect for and their personal connection to the deceased, framing their performance as an acknowledgement of particular kinship and marriage ties.

A number of scholars have remarked on the important role that song and dance plays as part of mortuary rites both in this region and throughout Aboriginal 
society. ${ }^{10}$ Music not only interacts with and directs the ritual action of the bereaved - as in the passage above where the Karrbarda songs cue the departure of the coffin and the outpouring of grief - it also influences and interacts with the spirit world. Analysing the performance of wangga at rag-burning (mortuary) ceremonies in the Daly region, Allan Marett describes how elements of the music and the dance reference both the ghostly and human worlds. By overlapping these elements in the performance, the living are brought into a liminal space with the spirits, enabling the spirit of the deceased to exit the world of the living and enter the world of the ancestors who reside in the Country. ${ }^{11}$ Following Marett's analysis, I argue that the performance of kun-borrk - the Bininj Gunwok name for western Arnhem Land public dance-accompanied songs (also referred to as manyardi in Mawng language $)^{12}$ — at funeral ceremonies facilitates a kind of creative exchange between the living and the dead. In this exchange, songmen construct their performance partly for the benefit of spirits, while the spirits give them new songs in their dreams to perform for the occasion, and take part in - even influence - their ceremonial performance. This circulation of songs between the living and the dead is ultimately productive in sustaining the song tradition: as long as songs that were handed down continue to be performed in ceremony, the possibility of new compositions in the future - via spirit intervention in dreams-remains. ${ }^{13}$

The first section of this chapter provides an overview of the role of funerals in Aboriginal society, and the influence of Christianity on contemporary funeral rites in western Arnhem Land. I discuss Aboriginal spiritual beliefs about the cycle of life and death and the important place of dream-conceived spiritlanguage songs in fulfilling this cycle. In western Arnhem Land, the language of the songs is fundamental to this ongoing connection between the living and the dead, because of the way it communicates with the spirit world. The ancestors

\footnotetext{
10 Some earlier studies include Ronald Berndt's overview of mortuary rituals in northern Australia: Ronald M. Berndt, Australian Aboriginal Religion (Leiden: E. J. Brill, 1974), 23-31. See also Spencer's description of mortuary ceremonies of Gaagadju at Oenpelli: Baldwin Spencer, Native Tribes of the Northern Territory of Australia (London: Macmillan, 1914). Morphy, Reid, and Warner give accounts of Yolngu funeral ceremonies in east Arnhem Land: Howard Morphy, Journey to the Crocodile's Nest: An accompanying monograph to the film Madarrpa funeral at Gurka' wuy (Canberra: Australian Institute of Aboriginal Studies, 1984); Janice Reid, 'A Time to Live, a Time to Grieve: Patterns and processes of mourning among the Yolngu of Australia', Culture, Medicine and Psychiatry 3:4 (1979); Lloyd W. Warner, A Black Civilization: A social study of an Australian tribe (Gloucester: P. Smith, 1969). More recent perspectives on contemporary attitudes to death in Aboriginal Australia are discussed in Katie Glaskin, Myrna Tonkinson, Yasmine Musharbash, and Victoria Burbank, eds. Mortality, Mourning and Mortuary Practices in Indigenous Australia (Surrey: Ashgate, 2008).

11 Allan Marett, 'Ghostly Voices: Some observations on song-creation, ceremony and being in north western Australia', Oceania 71:1 (2000): 24-5.

12 For the purposes of this chapter, I adopt the Bininj Gunwok term, unless differentiating between songs of the two language groups.

13 Funeral ceremonies are the primary occasions in which kun-borrk is performed, however other occasions include circumcision ceremonies, gift exchange ceremonies, official community events such as the opening of a building or cultural festivals, and informal settings such as around the campfire.
} 
who first performed the songs (and handed them down to successive male relatives) understand the song text (even if the living do not), and the songs that current songmen receive from them contain the same words.

The second section discusses the diverse network of sociality represented in the funeral ceremony for Nakodjok, which brought together Aboriginal people from the Tiwi Islands, east Arnhem Land and western Arnhem Land. I outline the different song traditions that were represented, the sequence in which they were performed during the ceremony, and discuss how the music reflected the western Arnhem Land singers' relationship with the deceased. Finally, I examine a performance of a kun-borrk song repertory called Mirrijpu (M: seagull), on the penultimate evening of the funeral ceremony for Nakodjok before his burial at Mikkinj Valley. Based on insights provided by the Mirrijpu songmen - whom I accompanied to the burial - about the choices they made in ordering the songs, as well as my own analysis of changes in tempo and clapstick beating, I discuss how the performance was constructed with an awareness of both the funeral mourners and the spirits of the deceased.

\section{Background to the Event}

Nakodjok Nayinggul was an important ceremony man and senior traditional owner of Country surrounding Gunbalanya and parts of Kakadu National Park. He was well known and respected by both Bininj and Balanda. I met him in 2011 during fieldwork which involved repatriating digital recordings of song and other documentation of Bininj cultural activities, produced during the 1948 American-Australian Expedition to Arnhem Land, with the aim of understanding these recordings from a Bininj perspective. Not long after I arrived at Gunbalanya, a ceremony was held to conduct a repatriation of a different kind, which was once again connected to the Arnhem Land Expedition: the return of physical remains to Oenpelli, taken at different stages in the twentieth century, including by archaeologist Frank Setzler in 1948. A re-burial ceremony was carried out by traditional owners of Gunbalanya, led by Nakodjok, with members of government, museums, local organisations, and researchers giving assistance. ${ }^{14}$ As with Nakodjok's funeral ceremony one year later, I took part by helping out where it was needed-with transport, logistics (organising the hire of an amplification system for outdoor speeches and operating music played over the speakers) and catering. During the reburial ceremony, I was introduced to kun-borrk singers resident at Gunbalanya, including Mirrijpu (M: seagull), Inyjalarrku (M: mermaid) and Karrbarda (K: long yam) singers and dancers. Solomon Nangamu, lead singer for Mirrijpu, invited me to record

14 See Thomas, this volume. 
the songs performed for this reburial ceremony, and later to accompany him to other ceremonial occasions that he attended during my time in western Arnhem Land. My project involving repatriation of digital records therefore led to a documentation project of a living song tradition in western Arnhem Land, focusing on Nangamu's performances with other western Arnhem Land songmen that we met along the way. By showing me how kun-borrk continued to operate in contemporary life, Nangamu and other songmen were able to shed light on the older kun-borrk recordings made by Simpson. ${ }^{15}$

\section{Mortuary Rites in Aboriginal Society}

\section{Contemporary Funerals in Western Arnhem Land}

Funerals are an important feature of Aboriginal life in Australia. Aboriginal societies are kinship-based; in western Arnhem Land as in other areas of Australia, Bininj are born into a particular skin group or subsection that gives everyone a relationship with one another, ensuring that no one is a complete stranger. ${ }^{16}$ When someone passes away, close kin come together at the funeral ceremony to play their part in assisting the bereaved and to express their own feelings of loss for the deceased. ${ }^{17}$ In east Arnhem Land and parts of western Arnhem Land, ritual managers of the deceased and of the Country where the ceremony takes place-referred to as djungkay (K) - help to coordinate the various stages of the funeral ceremony. In the dry season when the roads are open-making it easier to travel to and from towns and outstations in Arnhem Land - funerals may occur on a weekly basis. Before my arrival at Gunbalanya, I had only ever attended two funerals. In my second year in western Arnhem Land, I attended five, and was aware of another half dozen that took place during my stay.

Funeral ceremonies are also a significant part of Aboriginal cultural and spiritual expression. Aboriginal people anticipate death; those who are elderly and are dying generally become the focus of community interest rather than being shut

\footnotetext{
15 Simpson's recordings at Gunbalanya are also discussed by Anthony Linden Jones (this volume). I analyse Bininj responses to Simpson's recordings at Oenpelli in my thesis. Reuben Brown, Performance as Exchange: The role of western Arnhem Land song traditions in contemporary society ( $\mathrm{PhD}$, Sydney Conservatorium of Music, The University of Sydney, 2014 forthcoming).

16 For an overview of systems of kinship in Aboriginal Australia, see Ian Keen, Aboriginal Economy and Society: Australia at the threshold of colonisation (South Melbourne: Oxford University Press, 2004), 174-209. For western Arnhem Land kinship names, see Khaki Marrala, Kindi Ngamin Nuwung? What Do I Call You? 'Ma!'. Vol. 1, (Jabiru: Iwaidja Inyman, 2008).

17 See Myrna Tonkinson, 'Solidarity in Shared Loss: Death-related observances among the Martu of the Western Desert', in Mortality, Mourning and Mortuary Practices in Indigenous Australia, eds Katie Glaskin et al. (Surrey: Ashgate, 2008).
} 
away, and mourning rituals take place over a long period of time-sometimes years. ${ }^{18}$ As Morphy and Morphy suggest, the way that Aboriginal cultures deal with death is for many people a marker of their Aboriginality:

All over Australia, it seems, and in very different colonial settings, the rituals surrounding death have become a constant theatre of life, where, in a relatively autonomous space indigenous values are affirmed and asserted, with greater or lesser degrees of consciousness, in contrast to those of the encapsulating society. ${ }^{19}$

Throughout Arnhem Land an elaborate secondary burial ceremony called the lorkkon traditionally took place some years after the initial burial, in which the bones of the deceased would be excavated, rubbed in red ochre and placed in a log hollowed out by termites and decorated with clan emblems (the lorrkkon). ${ }^{20}$ This ceremony represented the final departure of the spirit of the deceased from the world of the living. Over time, Aboriginal people of Arnhem Land have adapted their funeral ceremonies to various advances in technology, as well as a number of social changes, including the influence of missionaries who brought Christian beliefs and rituals. The lorrkkon ceremony met with the disapproval of missionaries, who believed that bodies buried on 'consecrated' ground should not be disturbed. ${ }^{21}$ As a consequence, along with other factors including the passing of senior elders who held important knowledge about how to conduct lorrkkon, the ceremony has been replaced with a single, final burial. ${ }^{22}$

Contemporary funeral ceremonies usually incorporate a Christian service into the ceremony. This may involve a sermon and hymns as part of an earlier memorial service for the community in the church (if the deceased was well-known) and a separate sermon for the burial, as was the case for Nakodjok Nayinggul. In Spencer's account of Bininj ceremonial life at Gunbalanya (then referred to as Oenpelli) in 1912, initial burials were held the day after someone passed away, and were not as prolonged as they can be today. ${ }^{23}$ In western Arnhem Land, the deceased may be flown to a central morgue in Darwin or Katherine and kept there for some months while the family wait for relatives from other areas of Arnhem Land to come and attend the funeral ceremony. In the earlier part

18 Morphy, Journey to the Crocodile's Nest, 37.

19 Howard Morphy and Frances Morphy, 'Afterword: Demography and destiny', in Mortality, Mourning and Mortuary Practices in Indigenous Australia, eds Katie Glaskin, Myrna Tonkinson, Yasmine Musharbash and Victoria Burbank (Surrey: Ashgate, 2008), 210-11.

20 Margaret Clunies Ross and Stephen A. Wild, 'Formal Performance: The relations of music, text and dance in Arnhem Land clan songs', Ethnomusicology 28:2 (1984): 210. The ceremony is depicted in the film Waiting for Harry for a funeral that takes place east of Maningrida. Kim McKenzie, Waiting for Harry (Canberra: Australian Institute of Aboriginal Studies, 1980).

21 See Morphy, Journey to the Crocodile's Nest, 44-5.

22 Reid observes that lorrkkon is no longer widely practiced in north-east Arnhem Land. Reid, 'A Time to Live, a Time to Grieve', 328.

23 Spencer, Native tribes of the Northern Territory, 240. 
of the twentieth century when missionaries established themselves in Arnhem Land, funerals were more frequently held at missions, settlements or towns, whereas today, due to the availability of charter planes, the ceremony can be held at outstations and the deceased can be buried on their Country. ${ }^{24}$ This often means that the ceremony requires significant pooling of money and resources to organise and can last weeks, while the family waits for an important person to attend.

\section{The Role of Song in Effecting the 'Life Cycle' of the Spirit}

Although mortuary rites vary across northern Australia, they have in common a purpose beyond allowing for a process of grieving: to ensure that the spirit of the deceased no longer dwells among the living (potentially causing them trouble or danger), and is satisfied to leave, joining the ancestral dead and returning to its Country. Underpinning this journey is the belief in what some have referred to as the 'life cycle' ${ }^{25}$ or 'existence cycle' ${ }^{26}$ of the spirit. In some areas of northern Australia, a person's spirit is believed to emerge from a specific totemic Dreaming site that is associated with fertility, while in others, such as the Daly region, it emerges from 'fairly broadly defined stretches of country'.${ }^{27}$ The spirit then enters the mother's womb and takes up residence in the human body. When a person dies they become a spirit again, initially dwelling near the place where they lived. ${ }^{28}$ In western Arnhem Land, after someone dies, Bininj immediately take branches from the ironbark tree, place them in a metal drum and set them alight, spreading the smoke through the houses where the deceased lived, as well as other places where that person spent significant time (the medical clinic or the local art centre, for example). Vehicles are also ceremonially smoked and in some cases when a songman dies, his songs are performed and simultaneously smoked, before a period of dormancy where they are not performed. ${ }^{29}$

Songs play a vital role in the deceased spirit's transition from the living world. North-east Arnhem Land mortuary rites involve the performance of ritual episodes or individual 'song series' according to a conceptual movement

\footnotetext{
24 For further discussion about the significance of burial on Country, see Deborah B. Rose, Dingo Makes Us Human: Life and land in an Australian Aboriginal culture (Cambridge: Cambridge University Press, 2009), 73.

25 Berndt, Australian Aboriginal Religion, 25; Morphy, Journey to the Crocodile's Nest, 32.

26 Marett, 'Ghostly Voices': 24.

27 ibid

28 See Thomas, this volume.

29 The period of time that songs remain dormant after death varies widely, and depends on the individual who inherits the songs. In this sense, as Barwick and Garde have suggested, kun-borrk songs in western Arnhem Land are more like 'personal property', as opposed to manikay from north-east and central Arnhem Land songs which belong to one's father's clan. Linda Barwick and Murray Garde, personal communication, 14 January 2013. See also Ross and Wild, 'Formal Performance': 209.
} 
through the landscape, which takes the deceased spirit on a particular route to its ancestral Country. ${ }^{30}$ At Wadeye and Belyuen in the Daly region, burnim-rag ceremonies involve driving the spirit away through the ritual burning of 'rags' belonging to the deceased (clothes, bedding, cooking and hunting utensils and other prized possessions) in which the deceased spirit may have taken refuge. ${ }^{31}$ As Marett explains, the performance of song and dance brings together the living with the Walakandha (ghosts) of the spirit world:

By joining with their Walakandha ancestors, through singing their songs, playing didjeridu, dancing their dances, painting the masks of Walakandha [ancestral spirits] on their bodies, and witnessing the production of their ceremonial forms, the living participants draw close to and interpenetrate with the dead. It is within this context that the spirits of the deceased are released from their attachments to the living and are freed to join the ancestral dead. ${ }^{32}$

While individual beliefs about what happens to the spirit of the deceased vary in western Arnhem Land, the function of music and dance is generally understood as it is in the Daly region: to coax the deceased spirit to return once more to its ancestral Country, where other ancestral spirits live. Re-absorbed in the landscape, the spirit is 'able to hear human voices, smell human presences, respond to human footprints', and may enter the womb of another Bininj where it will start the life-cycle once more. ${ }^{33}$

Songs at funeral ceremonies in western Arnhem Land do not follow a broader narrative or specific journey as they do in north-east Arnhem Land. However, similar principles relating to how the deceased spirit is oriented back to its Country affect the presentation of different songs, depending on the origin of those songs. Kun-borrk song repertories - referred to here as song-sets ${ }^{34}$ are generally thought of as belonging to one of two subcategories: wardde-ken (K: 'of the stone country') - referring to the Arnhem Land plateau area-and kurrula (M: sea; saltwater country) along the north-western coast of Arnhem

30 See Fiona Magowan, Melodies of Mourning: Music and emotion in northern Australia, (Crawley: University of Western Australia Press, 2007); P. G. Toner, 'Tropes of Longing and Belonging: Nostalgia and musical instruments in northeast Arnhem Land', Yearbook for Traditional Music 37 (2005): 4.

31 Marett, 'Ghostly Voices': 25-6.

32 Marett, Songs, Dreamings, and Ghosts, 31.

33 Marett, 'Ghostly Voices': 24-5.

34 Ronald and Catherine Berndt refer to kun-borrk repertories as 'song cycles'. Ronald M. Berndt, Love Songs of Arnhem Land (Melbourne: T. Nelson, 1976). However, following recent scholars such as Barwick et al., O'Keeffe and Garde, I use the term 'song-sets', since this does not imply a complete corpus of ordered songs. See Linda Barwick, Bruce Birch, and Nicholas Evans, 'Iwaidja Jurtbirrk Songs: Bringing language and music together', Australian Aboriginal Studies 2 (2007); Isabel O'Keeffe, 'Sung and Spoken: An analysis of two different versions of a Kun-Barlang love song', Australian Aboriginal Studies 2 (2007); Garde, 'The Language of Kun-borrk in Western Arnhem Land', Musicology Australia 28 (2006). 
Land, including the Coburg Peninsula and Goulburn and Croker Islands. ${ }^{35}$ If the deceased was from wardde-ken country for example, wardde-ken songs would be performed last, at the moment of burial. This was the case during the reburial ceremony in 2011 for the repatriated remains of people taken in 1948 whose traditional Country was Gunbalanya (wardde-ken). In the following passage, Mirrijpu songman Solomon Nangamu explains how the journey that the spirits of the remains had taken from Washington to Gunbalanya was metaphorically enacted through the performance of kun-borrk. Specifically, he discusses the choice first to perform his kurrula songs as the mourners made their way from the north of the town where the bones had been stored and prepared for burial, before reaching the burial ground facing the Arnhem Land plateau, where the wardde-ken singers took over the singing:

I'm from the saltwater country, I was born there. So when the bones [from Washington] arrived here [in Australia], I came and collected the bones and I took it and gave it to all the stone [country] mob, from this country [Gunbalanya]. I passed it on to them, them mob now, them take it and bury it. ${ }^{36}$

Neither Nangamu nor the Karrbarda group physically handled the bones at any stage. Nangamu's explanation shows how the act of singing songs from a particular Country is understood to carry the spirit through that Country - in his case, collecting the spirits from the north coast of Arnhem Land after they had crossed the Pacific Ocean from the US, and bringing them to the wardde-ken people of Gunbalanya.

Kun-borrk song-sets consist of a number of individual song items, which are collectively named after animals, plants, and spirit beings specific to the region-(seagull, long yam, mermaid, etc.). The dances and body paint designs that accompany the performance of these songs-sets often relate to the name given to the songs. For example, when women dance Karrbarda, their arm movements imitate digging the yam and carrying it above their heads with their dilly bags (see Figure 1). Each song-set contains one or two songs referred to as nigi in Mawng, meaning 'mother' ${ }^{37}$ These songs are recognisable by the fact that they have the slowest tempo of all of the songs, and are considered the essence of the song-set (the other songs, which have similar melodies and words, are its children). In western Arnhem Land funerals, the nigi is always performed last, to finish off the performance of the song-set and carry the deceased home. During the nigi song, the singers and didjeridu player will often stand up and

35 For further discussion, see Barwick et al., 'Iwaidja Jurtbirrk songs', 9.

36 Solomon Nangamu, interview with the author, August 2011.

37 In Kunwinjku, the 'mother' song is referred to as ngalbadjan. 
walk over to the grave (sometimes the leading songman may dance himself), while the women line up in the direction of the deceased's Country, and dance them into the grave.

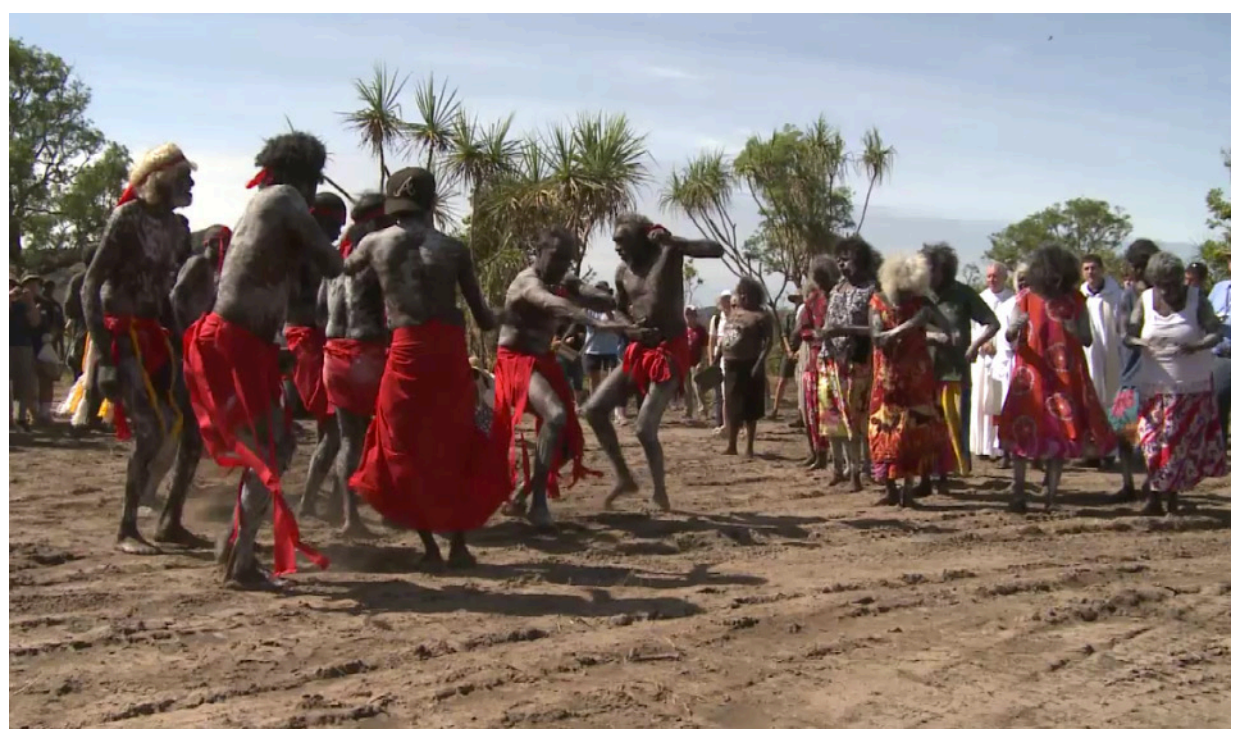

Figure 1: Bininj (left) and daluk (right) dance Karrbarda at Gunbalanya, 2011, as part of a reburial ceremony for bones taken during the Arnhem Land Expedition. Photograph by Addis Hondo.

Source: By permission of photographer.

Funeral ceremonies are important occasions for the presentation of newly composed songs, which arise when deceased spirits intervene in a songman's dreams and inspire new musical material for him to sing as part of his inherited song-set. Dreams act as a kind of portal through which certain songmen gain access to the spirit world, and the presence of spirits may be heightened during the period after death and leading up to the funeral. The significance of dreamcomposed songs has been discussed elsewhere by Marett with regard to wangga of the Daly region, ${ }^{38}$ and by Treloyn with regard to Scotty Martin's junba of the Kimberley region. ${ }^{39}$ Barwick, Birch and Evans have observed that in western Arnhem Land, songs that come from dreams are given the status of 'true' songs, as opposed to songs that come to the singer 'spontaneously' without spirit intervention. ${ }^{40}$ As Murray Garde notes, kun-borrk songmen establish authority

38 Marett, Songs, Dreamings, and Ghosts, 36-45.

39 Sally Treloyn, 'Scotty Martin's Jadmi Junba: A song series from the Kimberley region of northwest Australia', Oceania 73:3 (2003).

40 Barwick et al., 'Iwaidja Jurtbirrk songs', 9. 
over their song repertories through the way that they access 'new' songs through the supernatural, interpret these songs given by spirits, and continue to perform the songs in ceremony. ${ }^{41}$

The language of kun-borrk songs are an important component linking people to ancestral spirits of the Country. Each kun-borrk song-set is associated with one or more of the languages of western Arnhem Land (see Figure 2). Many song-sets are associated with languages that are no longer spoken (the Mirrijpu song-set associated with Manangkardi, for example) or are highly endangered (the Karrbarda song-set associated with Kunbarlang, for example); ${ }^{42}$ therefore songs are a powerful means of communicating with ancestors who spoke these languages. Song texts can be in one or more 'ordinary' languages (reflecting the multilingual environment of Bininj in western Arnhem Land), ${ }^{43}$ as well as what has been referred to by various scholars in the literature on north Australian songs as 'spirit language'. ${ }^{44}$ Spirit languages are regarded as belonging to songgiving spirits who live in the landscape. As Mirrijpu songman Russell Agalara explains, 'it's not any language that we speak now, that's a different language from back then, passed on from generation to generation' ${ }^{45}$ In Mawng the term for these song words is wurrgal ngaralk, which translates as 'dream words' ${ }^{46}$ These untranslatable spirit language words are 'fixed' in song; unlike improvised vocables (as in jazz scat singing), they vary little from one performance to the next. ${ }^{47}$ As Meiki Apted found with regard to the Inyjalarrku song-set, spirit language words are distinct from but also sound similar to the 'ordinary' language of the singers (in this case, Mawng). ${ }^{48}$ They are particularly potent in the context of funeral ceremonies because they 'speak' exclusively to ancestral

\footnotetext{
41 Garde, 'The language of Kun-borrk', 86.

42 The Karrbarda song-set, predominantly in spirit language, also incorporates Bob Balir-Balir's 'everyday' language songs in Kun-barlang (after which the song-set is also known). See O'Keeffe, 'Sung and Spoken', 48. 43 Most Bininj speak three or four Aboriginal languages and it is not uncommon for a song text to switch between languages within the song. See Isabel O'Keeffe, 'Kaddikkaddik Ka-Wokdjanganj “Kaddikkaddik Spoke": Language and music of the Kun-barlang Kaddikkaddik songs from western Arnhem Land', Australian Journal of Linguistics 30:1 (2010).

44 See Meiki Elizabeth Apted, 'Songs from the Inyjalarrku: The use of a non-translatable spirit language in a song set from north-west Arnhem Land, Australia', Australian Journal of Linguistics 30:1 (2010): 94; Garde, 'The Language of Kun-borrk': 78-81; O'Keeffe, 'Sung and Spoken': 46. Marett also discusses spirit language in various texts of wangga songs of the Daly region. Marett, Songs, Dreamings, and Ghosts.

45 Russell Agalara, Reuben Brown, and Solomon Nangamu, 'That Spirit Changed My Voice: The performance of kun-borrk at a funeral ceremony in Mikkinj Valley, western Arnhem Land', Paper presented at the Musicological Society of Australia Annual Conference, The Australian National University, Canberra, 3-5 December 2012.

46 Rosemary Urabadi, personal communication, 6 November 2012.

47 Apted, 'Songs from the Inyjalarrku': 93-4. See also Garde, 'The Language of Kun-borrk': 81. From my observations of the Mirrijpu song-set, the current singer may realise the spirit language words in song slightly differently from the singer that passed on the songs, as part of their own interpretation of the music.

48 Apted, 'Songs from the Inyjalarrku': 98-100.
} 
spirits who understand them. As Apted observes, by singing spirit language songs, 'spiritual faith and connection to country is asserted in a way that may not be possible with an ordinary spoken language' ${ }^{49}$

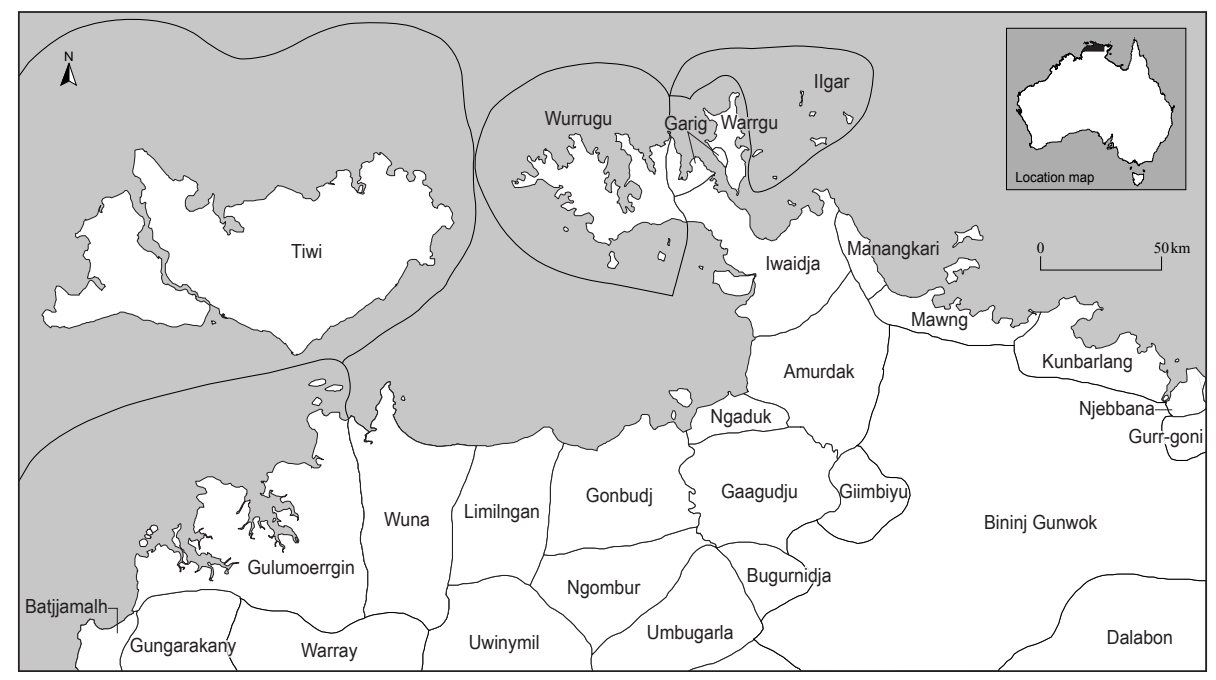

Figure 2: The languages of western Arnhem Land and surrounds.

Source: Aidan Wilson, Tiwi Revisited: A reanalysis of traditional Tiwi verb morphology (Masters, University of Melbourne, 2013), xii. Reproduced by permission of Aidan Wilson.

\section{The Funeral Ceremony for Nakodjok}

\section{Song Repertories Performed and their Sequence in the Ceremony}

Whilst it is not unusual to find a number of different song genres and repertories performed at funerals or indeed any ceremonial occasions in western Arnhem Land, ${ }^{50}$ the funeral ceremony for Nakodjok Nayinggul was particularly unique, in that it brought together such a diverse range of song traditions from all over the broader region of the Top End. All together, seven different Aboriginal song

49 Apted, 'Songs from the Inyjalarrku': 101.

50 Funeral ceremonies that I attended in and around Gunbalanya during my fieldwork commonly featured two or three song-sets by singers both residing in the region of the deceased or visiting from outside the region, usually from central Arnhem Land or the Daly region. Barwick and Marett's findings about the origins of Colin Simpson's recordings at Oenpelli/Gunbalanya in 1948 similarly reveal an assortment of songs from all over the region (three kun-borrk 'love songs', two kun-borrk wardde-ken songs, two manyardi kurrula songs and one wangga song). See Linda Barwick and Allan Marrett, 'Snapshots of Musical Life: The 1948 recordings', in Exploring the Legacy of the 1948 Arnhem Land Expedition, eds Martin Thomas and Margo Neale (Canberra: ANU E Press, 2011), 364. 
groups performed at various stages of the ceremony (see Figure 3). Of equal significance was the music not representative of Aboriginal Australian genres that featured in the ceremony, including Christian hymns in Kunwinjku led by the local Reverend and sung by the congregation, as well as various country and western songs that were played through speakers on an mp3 player at Nakodjok's memorial service. The high participation from a diversity of singers in the ceremony reflected not only Nakodjok's importance as a leader in his immediate community of Gunbalanya and western Arnhem Land, but also showed how Bininj like Nakodjok have kinship ties right across Arnhem Land and the Top End region.

\begin{tabular}{|c|c|c|c|c|}
\hline Song-set & Genre & Singer & \begin{tabular}{|l} 
Singer's \\
residence
\end{tabular} & Language \\
\hline $\begin{array}{l}\text { Inyjalarrku } \\
\text { (mermaid) }\end{array}$ & $\begin{array}{l}\text { western Arnhem } \\
\text { Land } \\
\text { manyardi }\end{array}$ & $\begin{array}{l}\text { David and Rupert } \\
\text { Manmurulu }\end{array}$ & $\begin{array}{l}\text { Warruwi } \\
\text { (Goulburn Island) }\end{array}$ & $\begin{array}{l}\text { Spirit language } \\
\text { associated with } \\
\text { Mawng }\end{array}$ \\
\hline $\begin{array}{l}\text { Inyjalarrku/ } \\
\text { Marrawiwi } \\
\text { (salmon) } \\
\end{array}$ & $\begin{array}{l}\text { western Arnhem } \\
\text { Land } \\
\text { manyardi }\end{array}$ & Tommy Madjalkaidj & $\begin{array}{l}\text { Maningrida } \\
\text { (born Warruwi) }\end{array}$ & $\begin{array}{l}\text { Spirit language } \\
\text { associated with } \\
\text { Mawng }\end{array}$ \\
\hline $\begin{array}{l}\text { Mirrijpu } \\
\text { (seagull) }\end{array}$ & $\begin{array}{l}\text { western Arnhem } \\
\text { Land } \\
\text { manyardi }\end{array}$ & $\begin{array}{l}\text { Solomon Nangamu } \\
\text { and Russell Agalara }\end{array}$ & $\begin{array}{l}\text { Gunbalanya } \\
\text { (born Warruwi) }\end{array}$ & $\begin{array}{l}\text { Spirit language } \\
\text { associated with } \\
\text { Manangkardi }\end{array}$ \\
\hline $\begin{array}{l}\text { Karrbarda } \\
\text { (long yam) }\end{array}$ & $\begin{array}{l}\text { western Arnhem } \\
\text { Land kun-borrk }\end{array}$ & Eric Mardday & Gunbalanya & $\begin{array}{l}\text { Spirit language, } \\
\text { Kun-barlang, Mawng } \\
\text { and Kunwinjku mixed }\end{array}$ \\
\hline $\begin{array}{l}\text { Ramingining } \\
\text { singers } \\
\text { (unknown clan) } \\
\end{array}$ & $\begin{array}{l}\text { central Arnhem } \\
\text { Land } \\
\text { bunggurl }\end{array}$ & Stanley Djalarra & Ramingining & Rembarrnga \\
\hline Galpu clan & $\begin{array}{l}\text { north-east Arnhem } \\
\text { Land manikay }\end{array}$ & $\begin{array}{l}\text { Gurruwiwi family } \\
\text { (and Johnny } \\
\text { Burarrwanga) }\end{array}$ & $\begin{array}{l}\text { Warruwi } \\
\text { (born Gove) }\end{array}$ & Yolngu Matha \\
\hline Buffalo dance & Tiwi kulama songs & $\begin{array}{l}\text { Wesley Kerunauia } \\
\text { (and Solomon } \\
\text { Nangamu) }\end{array}$ & Bathurst Island & Tiwi \\
\hline $\begin{array}{l}\text { Christian } \\
\text { hymns }\end{array}$ & $\begin{array}{l}\text { Anglican church } \\
\text { music }\end{array}$ & $\begin{array}{l}\text { Congregation } \\
\text { led by Rev. Lois } \\
\text { Nadjamerrek }\end{array}$ & Gunbalanya & $\begin{array}{l}\text { Kunwinjku and } \\
\text { English }\end{array}$ \\
\hline Various artists & $\begin{array}{l}\text { country and } \\
\text { western }\end{array}$ & $\begin{array}{l}\text { Troy Cassar-Daley } \\
\text { Slim Dusty } \\
\text { Charley Pride }\end{array}$ & $\begin{array}{l}\text { Australia } \\
\text { America }\end{array}$ & English \\
\hline
\end{tabular}

\section{Figure 3: Songs performed or played at the funeral ceremony for Nakodjok.}

Unsurprisingly, the majority of the singers who performed at Nakodjok's ceremony were from western Arnhem Land, the region in which Nakodjok was born and where he spent most of his life. Many of the song repertories performed were manyardi song-sets originating from Goulburn Island. This is owing to the fact that numerous Mawng songmen who were born on Goulburn 
Island today reside not only in the community of Warruwi (Goulburn Island)arguably the centre of the western Arnhem Land song tradition today-but also in other neighbouring communities, where they continue to perform the songs and receive new songs. The Inyjalarrku song-set is a good example of the way manyardi has spread throughout western Arnhem Land on account of the Goulburn Island 'diaspora'; the songs have been inherited by a number of singers including David Manmurulu, his brother James Gulamuwu, and Tommy Madjalkaidj, ${ }^{51}$ who today live in Warruwi, Gunbalanya and Maningrida respectively. ${ }^{52}$ Only one song-set performed at the funeral-Karrbardaoriginated from wardde-ken (the stone country) where Nakodjok's Country is situated. ${ }^{53}$ This song-set, (also performed by inheriting singers living on Croker Island, Maningrida and Gunbalanya), plays a central role in many funeral ceremonies held in Gunbalanya.

Perhaps more unusually, a number of songs from outside western Arnhem Land were represented, including patrilineal clan 'song series' from central and north-east Arnhem Land, referred to as bunggurl and manikay respectively. Each clan performs a number of song subjects in a series that relate to different aspects of their ancestral stories. ${ }^{54}$ Although I was unable to establish the clan affiliation of the group from Ramingining, the most prominent subject of their songs was the Waak (K: crow), which was accompanied by a dance that imitates the bird's movement and sound. (The dancers circled and hopped as they moved toward the gravesite, calling out 'waak, waak!'). Crows are associated with death in this region, and Waak manikay are often performed during the final stages of burial. ${ }^{55}$ Galpu manikay was also performed by the Gurruwiwi family and accompanied by Gumatj clan singer Johnny Burarrwanga, who was born in east Arnhem Land and married a Galpu clan woman. Burarrwanga lives with other Galpu and Gumatj people who have long been resident at Warruwi, but who still maintain their manikay performance traditions by performing in western Arnhem Land.

Not only are these song series from central and north-east Arnhem Land different from those from western Arnhem Land in the way that they are inherited (through one's clan as opposed to individually), they also sound different in a number of ways. Unlike western Arnhem Land songs, north-east Arnhem Land

\footnotetext{
51 The fathers of these songmen were part of the same family and shared the songs.

52 Solomon Nangamu — singer of the third manyardi Mirrijpu song-set of North Goulburn Island — was also born in Warruwi, and now resides in the larger community of Gunbalanya where he lives with his Kunwinjku fiancée.

53 Another wardde-ken song-set called Kurri (K: blue tongue lizard) is also more closely associated with Nakodjok's Country and is well remembered by his family. However, as far as I have observed, this song-set is no longer performed.

54 Ross and Wild, 'Formal Performance': 9; Toner, 'Tropes of Longing and Belonging': 4.

55 Clunies Ross and Wild, 'Formal Performance': 213. Also depicted in the final scenes of the lorrkkon ceremony in McKenzie, Waiting for Harry.
} 
melodies do not necessarily take their pitch from the didjeridu, and both northeast and central Arnhem Land songs feature didjeridu overtones that are absent from western Arnhem Land mako accompaniment. There are subtle differences in layering of the musical texture too: whereas kun-borrk/manyardi begins with didjeridu accompaniment, followed by the beat of the clapstick and then the vocal line, and ends with solitary beating of the clapsticks, manikay/bunggurl songs often begin with clapstick accompaniment and finish with unaccompanied singing. These aural characteristics make the geographic identity of the songs instantly recognisable to mourners in larger funeral ceremonies such as Nakodjok's, where different groups performed simultaneously, both in the daytime and in the evening. ${ }^{56}$

The last genre of Aboriginal songs from outside Arnhem Land was Tiwi songs associated with the kulama (yam) ceremony. These songs were performed unaccompanied (without clapsticks or didjeridu) led by Wesley Kerunauia, with Dean Rioli and Solomon Nangamu joining the dancing (Nangamu lived in Tiwi for a number of years and was invited to join as he was familiar with the songs). The dance they performed - referred to as the 'buffalo' - took place next to the grave, after the coffin was put in the ground..$^{57}$ The melody of the song had a limited range, resembling something closer to speech. Each song culminated in a percussive slap of the body, followed by the distinctive dance call: 'ah-eh-yah' .

Of the Western musical genres performed, Reverend Lois Nadjamerrek and a small congregation of Bininj sang unaccompanied Christian biblical hymns during the memorial service in the church at Gunbalanya, and as part of an open-air sermon by the gravesite at Mikkinj Valley, as the grave was being filled (see Figure 4). Nadjamerrek led the service in both Kunwinjku and English, and composed one of the hymns in Kunwinjku. In addition, the family of Nakodjok requested three particular songs to be played at the end of the memorial service, as the mourners said goodbye to the coffin. The first song-'Gunbalanya' by Troy Cassar-Daley - pays homage to Nakodjok's Country, with references to fishing for saratoga at Red Lily billabong near the East Alligator River. CassarDaley is an Indigenous country and western singer from New South Wales who travelled to Gunbalanya and met Nakodjok, later dedicating the song to him.

\footnotetext{
56 See Linda Barwick, 'Musical Form and Style in Murriny Patha Djanba Songs at Wadeye (Northern Territory, Australia)', in Analytical and Cross-Cultural Studies in World Music, eds Michael Tenzer and John Roeder (Oxford Scholarship Online: Oxford University Press, 2011), 349; Allan Marett, Linda Barwick, and Lysbeth Ford, For the Sake of a Song: Wangga songmen and their repertories: The Indigenous music of Australia, Book 2 (Sydney: Sydney University Press, 2013), 63.

57 Similar dances were photographed and described by Baldwin Spencer when he travelled to Melville Island in 1911. Spencer, Native tribes of the Northern Territory, 237.
} 


\begin{tabular}{|c|c|c|c|}
\hline $\begin{array}{l}6 \text { June } 2012 \\
\text { Gunbalanya: } \\
\text { Transition to } \\
\text { local morgue }\end{array}$ & $\begin{array}{l}28 \text { June } 2012 \\
\text { Gunbalanya: } \\
\text { Memorial service }\end{array}$ & $\begin{array}{l}29 \text { June } 2012 \\
\text { Mikkinj Valley: } \\
\text { Pre-interment }\end{array}$ & $\begin{array}{l}30 \text { June } 2012 \\
\text { Mikkinj valley: } \\
\text { Interment and } \\
\text { post-interment }\end{array}$ \\
\hline $\begin{array}{l}\text { Ramingining } \\
\text { singers sing } \\
\text { outside Nakodjok's } \\
\text { home while family } \\
\text { stays with coffin } \\
\text { inside. } \\
\text { Karrbarda dance } \\
\text { coffin out of house } \\
\text { and accompany } \\
\text { procession of } \\
\text { mourners to } \\
\text { Gunbalanya } \\
\text { morgue. } \\
\text { Ramingining } \\
\text { singers then take } \\
\text { over and sing } \\
\text { Nakodjok inside. }\end{array}$ & $\begin{array}{l}\text { Galpu manikay singers } \\
\text { accompany procession } \\
\text { from morgue to } \\
\text { church. } \\
\text { Upon arrival at church, } \\
\text { Mirrijpu singers lead } \\
\text { coffin and procession } \\
\text { of mourners into } \\
\text { church. } \\
\text { Reverend Lois } \\
\text { Nadjamerrek leads } \\
\text { Christian hymns in } \\
\text { English during service. } \\
\text { country and western } \\
\text { songs played over } \\
\text { PA as local mourners } \\
\text { farewell Nakodjok. } \\
\text { Inyjalarrku is performed } \\
\text { as the coffin is taken } \\
\text { from church to airport } \\
\text { and placed on plane to } \\
\text { Mikkinj Valley, where } \\
\text { Karrbarda greets it. }\end{array}$ & $\begin{array}{l}\text { Mirrijpu, } \\
\text { Raminging } \\
\text { singers and } \\
\text { Karrbarda } \\
\text { share singing } \\
\text { after sundown } \\
\text { while families } \\
\text { cook dinner in } \\
\text { separate camps. } \\
\text { Karrbarda } \\
\text { perform later } \\
\text { in the evening, } \\
\text { with children } \\
\text { joining in } \\
\text { dancing. } \\
\text { Mirrijpu take } \\
\text { over and } \\
\text { continue to sing } \\
\text { until early the } \\
\text { next morning. }\end{array}$ & $\begin{array}{l}\text { Mirrijpu, Inyjalarrku and } \\
\text { Karrbarda lead groups } \\
\text { of mourners into bough } \\
\text { shelter to farewell } \\
\text { Nakodjok. Ramingining } \\
\text { mob join them and all } \\
\text { groups dance outside } \\
\text { bough shelter. } \\
\text { Karrbarda 'mother' song } \\
\text { leads Nakodjok into } \\
\text { grave. Tiwi Island Buffalo } \\
\text { dance performed beside } \\
\text { the grave, followed } \\
\text { by Christian hymns in } \\
\text { Kunwinjku. } \\
\text { After interment, } \\
\text { Ramingining and Tiwi } \\
\text { Island group remain for } \\
\text { kun-woning (cleansing/ } \\
\text { washing ceremony) } \\
\text { followed by smoking } \\
\text { ceremony of Nakodjok's } \\
\text { belongings and home at } \\
\text { Mikkinj Valley. }\end{array}$ \\
\hline
\end{tabular}

Figure 4: The main stages of the funeral ceremony for Nakodjok involving ritual song and dance.

The second song, 'We've Done us Proud' by Slim Dusty is a nationalistic song about the progress of the Australian nation. Slim Dusty's music is well known in many Aboriginal communities in the Top End where he toured and performed throughout his career. ${ }^{58}$ The song resonates with the history of this area, in particular the Bininjowned cattle station at Gunbalanya ('I built the fences to hold the cattle/I worked the land'). Sentiments about uniting people together for a common good ('side by side, hand in hand') also resonate with Nakodjok's achievements as a key negotiator between Balanda and Bininj during his work for the Northern Land Council and as a board member of the joint-managed Kakadu National Park.

The third song - 'Blue Ridge Mountains' by African American singer Charley Pride - was, according to Nakodjok's son Alfred Nayinggul, a favourite of Nakodjok's because it reminded him of the landscape of his Country. Nayinggul recalled his father sitting outside at Mikkinj Valley outstation, listening to the song on the record player while taking in the surrounding escarpment. These

58 Jon Fitzgerald and Philip Hayward, 'At the Confluence: Slim Dusty and Australian country music', in Outback and Urban: Australian country music, ed. Philip Hayward (Gympie: AICM Press, 2003), 43. 
three songs indicate how country and western music in particular has come to be emblematic of Aboriginal experience and identification with the land, ${ }^{59}$ and how popular music genres have been incorporated into the Bininj world view, taking on meanings that are locally-specific (see also Mansfield, this volume).

The sequence in which the song repertories were performed (outlined in Figure 4) was partly determined by practical factors (such as who could attend the ceremonies at Gunbalanya and Mikkinj Valley), and partly negotiated by the parties involved so that certain song repertories could be emphasised at certain stages of the ceremony (see below for further discussion). Many Balanda and Bininj mourners who were unable to attend the burial at Mikkinj-including the manikay and manyardi singers resident at Warruwi - were given the opportunity to farewell the deceased after the memorial service at Gunbalanya. A number of people from the community and local organisations were asked by the family to speak about Nakodjok at the service. ${ }^{60}$ To the extent that it included Christian prayers and readings from the Bible conducted largely in English, a eulogy, hymns, and country and western songs, the Balanda-oriented memorial service complemented the ceremony at Mikkinj Valley, with its focus on Bininj rituals. This seemed fitting, given the bi-cultural world that Nakodjok had occupied.

Those groups who did not go on to Mikkinj accompanied Nakodjok from the morgue to the church for the service, including the Galpu clan, who performed manikay without didjeridu accompaniment, as well as David and Rupert Manmurulu who performed Inyjalarrku as Nakodjok's coffin was taken from the church and placed into a troopy, before it was transported by plane to Mikkinj Valley. Rupert Manmurulu led the singing of the Inyjalarrku 'mother' song, before David Manmurulu performed a dance that he had learnt from his father George Winungudj which is reserved for the end of such ceremonial occasions, when the dancers and singers say bobo (K/M: goodbye) to the spirit of the deceased. Unusually, the dance is performed at a moderate tempo normally reserved for women's dancing (see discussion of rhythmic modes below). Manmurulu took on the character of a yumparparr (M: giant spirit), standing in a semi-crouched position and swaying his arms as he walked to the beat of the clapstick, creating a sense of gravity through the movement. As the coffin was carried away, he extended both arms out to it and pulled them in to his chest, as if reaching out to make a connection, then held one arm out, rotating his hand as if waving 'goodbye' to the spirit of the deceased. ${ }^{61}$

\footnotetext{
59 See Clinton Walker, Buried Country: The story of Aboriginal country music (Sydney: Pluto Press, 2000). 60 For a Kunwinjku and English transcription of the eulogy given on behalf of Nakodjok's family, see Murray Garde, 'Nakodjok Namanilakarr,' Bininj Gunwok (blog), 27 June 2012, http://bininjgunwok.org.au/blog/page/3/. 61 This interpretation was informed by discussions with David Manmurulu, interview with the author, 3 November 2012.
} 


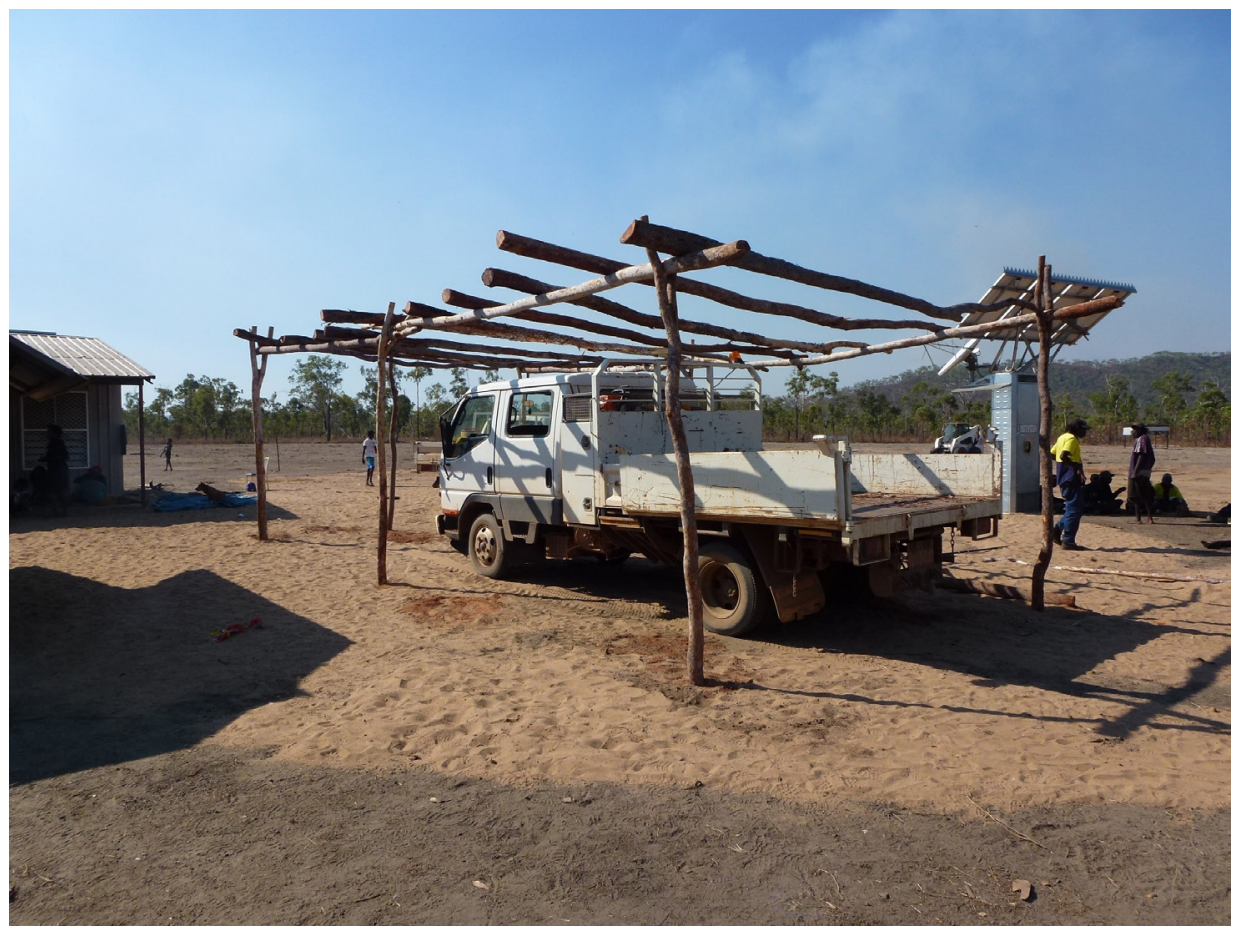

Figure 5: The construction of the bough shelter or 'shade' for the body of Nakodjok at Mikkinj Valley outstation.

Source: Photo by the author.

The Karrbarda and Ramingining singers stayed with the family of the deceased, many of whom did not attend the memorial service at Gunbalanya but awaited Nakodjok at Mikkinj Valley inside the bough shelter constructed for his coffin. Bough shelters are usually made of stringybark branches and leaves, providing shade for the mourners (see Figure 5). The shelter where the coffin is kept is an enclosed structure, sometimes covered in red or yellow cloth, representing the moiety of the deceased (Nakodjok's duwa moiety was represented with red cloth). The daluk members of the family stay inside the shelter beside the coffin until the burial. In the evening at Mikkinj Valley, the Karrbarda, Ramingining and Mirrijpu singers performed next to the shelter in order to keep the family company through the night. On the morning of the interment, Inyjalarrku singer Tommy Madjalkaidj joined them, performing 'old' Inyjalarrku songs as well 'new' dream-composed songs named Marrawiwi (M: salmon). Some of these newly conceived songs were performed for the first time in honour of the spirit of the deceased. Together, the four song groups took turns accompanying groups of mourners, including their own kin, into the bough shelter to visit Nakodjok one final time. Significantly, the Karrbarda group-representing wardde-ken people and their ancestors-performed the 'mother' song as the 
body was interred in order to carry Nakodjok's spirit away at the final moment. As the grave was being filled in, the opportunity arose for any other groups to pay their respects to the deceased, and the Tiwi group obliged, performing their Buffalo dance for Nakodjok. A Christian sermon and Kunwinjku hymns followed, concluding with a ritual in which the mourners throw a handful of dirt into the grave as a final goodbye.

\section{Relationships Expressed Through Song}

A number of significant connections between the living and deceased were enacted and highlighted through these performances at Nakodjok's funeral ceremony. As Peter Toner suggests, the choice to perform, as well as the sequence of the performance - which is decided not only among the singers but also other senior members of different patrifilial groups - are highly social and political acts in Arnhem Land ceremonies:

Yolngu musical performances are events in which complex social identities are expressed, negotiated, constructed, and re-constructed; they are occasions during which a great deal of the work of Yolngu sociality gets done at a number of different levels. ${ }^{62}$

Even the performance of Kunwinjku hymns, framed by a sermon delivered by Reverend Lois Nadjamerrek, in which she mentioned Nakodjok's baptism and first marriage that had taken place at the Gunbalanya church, ${ }^{63}$ emphasised his relationship to the local congregation and to God. Underpinning many of the social connections between the mourners and the deceased are cultural practices of clan exogamy (marriage outside one's own clan) ${ }^{64}$ and marriage agreements. The large representation of kurrula song-sets at Nakodjok's funeral reflected not only the prevalence of manyardi in western Arnhem Land, but also Nakodjok's connection to Mawng-speaking families through his mother, Priscilla, who was kurrula (from the saltwater). Nakodjok's father was wardde-ken (from the stone country) and helped resolve a dispute between the Gunbalanya and Goulburn Island communities. As thanks he was promised a Mawng woman (Priscilla) for marriage. ${ }^{65}$ This connection (between wardde-ken and kurrula people) was maintained when Priscilla made a pre-birth marriage agreement with the uncle of Tommy Madjalkaidj, that Nakodjok would marry Tommy (if he were a woman) or his sisters. Although the marriage didn't eventuate because Nakodjok was too young when the potential spouses were of the right age, Madjalkaidj and

\footnotetext{
62 Toner, 'Tropes of Longing and Belonging': 5-6.

63 See 'Book of Births, Deaths and Marriages' NTRS 864, Box 6, Location 75/5/4, Northern Territory Archives, Darwin.

64 See Barwick and Marett, 'Snapshots of Musical Life': 364-5.

65 Alfred Nayinggul, personal communication, 16 November 2012.
} 
Nakodjok recognised the fact that they were in an affinal relationship, and would refer to each other as brother-in-law. Madjalkaidj continued to recognise this relationship (marked by a degree of physical avoidance) during his performance at the ceremony, accompanying the mourners to the edge of the bough shelter with his Marrawiwi songs, but remaining outside while they went in. The Tiwi performance was given by family groups who were connected through two members of Nakodjok's family who shared ownership of his Country at Mikkinj Valley, but were taken away as children and sent first to Channel Island and then to Bathurst Island, where they had grown up. (Government policies affecting generations of stolen Aboriginal children have created a situation where family ties are spread far and wide.)

At the same time that performances highlight or emphasise connections between the mourners and the deceased, they also reinforce connections among the living, in particular through the rituals that are performed for the family of the deceased to guide them through the grieving process. On the evening before Nakodjok's burial, Mirrijpu singers Solomon Nangamu and Russell Agalara came together with didjeridu player Alfred Gawaraidji, and Karrbarda singers led by Eric Mardday, to take it in turns singing throughout the evening and into the next morning. Positioning themselves close to the family of the deceased inside the main bough shelter, they performed a mixture of moderate and fast-tempo songs (see Figure 6), encouraging the children to get up and join in the dance. The mood was high and the atmosphere jovial. The boisterous children kept themselves entertained through their own attempts to dance, and by watching the adults, including Madjalkaidj, dancing to the songs. As Agalara explained, part of the purpose of their singing and dancing at funerals is to keep the emotions of the bereaved in check so that they can not only mourn but also feel supported and happy. Explaining why they sing and dance, and its effect on the mourners, Agalara used the idiomatic Mawng expression arnamawu kumpil, which translates roughly as, 'they get a strong feeling in their chests' ${ }^{66}$

[By singing], we respect and we connect with their families among them ... being close to them ${ }^{67}$ [we] lift their feelings a bit ... they have sadness in their emotions and we ... arnamawu kumpil means we have to be there for them to express their emotions and balance it. ${ }^{68}$

Again on the morning of the burial, all of the song groups present performed fast songs, with Joey Nganjmirra and Russell Agalara taking turns playing the role of 'dance captain', helping the children to put on their nagas (dance-cloths)

\footnotetext{
66 This translation was assisted by Ruth Singer, who observes that the phrase is similar to an expression such as 'break (someone's) heart' in English. In this example, a transitive prefix is missing which would provide a clearer meaning of the expression. Ruth Singer, personal communication, 25 February 2013.

67 By singing next to the bough shelter.

68 Agalara, Brown, and Nangamu, 'That Spirit Changed My Voice'.
} 
and cover themselves in delek, and instructing those who were unfamiliar with kun-borrk how to dance to the various clapstick patterns. By bringing these different groups together to perform their song traditions and articulate their language/clan identities in the process, funeral events provide a much desired setting for the intergenerational transmission of song and dance traditions.

\begin{tabular}{|c|c|c|c|c|}
\hline \# & Song item & Song text association & Rhythmic mode & | Clapstick(bpm) \\
\hline 1 & MP01 & Kiwken (M: boss song) & Fast even & 124 \\
\hline 2 & MPO2 & $\begin{array}{l}\text { Bobo: bininj } \\
\text { (K: farewell song - men's dancing) }\end{array}$ & Fast even & 122 \\
\hline 3 & MP03 & $\begin{array}{l}\text { Bobo: daluk } \\
\text { (K: farewell song-women's dancing) }\end{array}$ & Moderate & 116 \\
\hline 4 & MP03 (R) & Bobo: daluk (K: farewell song-women) & Moderate & 117 \\
\hline 5 & MP03 (R) & Bobo: daluk (K: farewell song-women) & Moderate & 116 \\
\hline 6 & MP04 & Man-me (K: food; tucker) & Fast-doubled & 250 \\
\hline 7 & MP04 (R) & Man-me (K: food; tucker) & Fast-doubled & 244 \\
\hline 8 & MP05 & Ngaya (M: 'daughter') & Moderate & 117 \\
\hline 9 & MP05 (R) & Ngaya (M: 'daughter') & Moderate & 118 \\
\hline 10 & MP06 & Warramumpik (M: love song) & Fast even & 122 \\
\hline 11 & MP06 (R) & Warramumpik (M: love song) & Fast even & 120 \\
\hline 12 & MP06 (R) & $\begin{array}{l}\text { Warramumpik nulatparlangkat } \\
\text { (M: love song, fast rhythmic mode) }\end{array}$ & Fast-doubled & 264 \\
\hline 13 & MP04 & Man-me (K: food; tucker) & Fast-doubled & 260 \\
\hline 14 & MP07 & Ngapawurru (M: respect) & Moderate & 119 \\
\hline 15 & MP01 & Kiwken (M: boss song) & Fast even & 123 \\
\hline 16 & MP08/ MP09 & 'Going down' & Fast even & 122 \\
\hline 17 & MP08 & 'Going down' & Fast even & 124 \\
\hline 18 & MP08 (R) & 'Going down' & Fast even & 122 \\
\hline 19 & MP08 (R) & 'Going down' & Fast even & 123 \\
\hline 20 & MP09 & Bobo (K: farewell song) & Moderate & 118 \\
\hline 21 & MP09 (R) & Bobo (K: farewell song) & Moderate & 119 \\
\hline 22 & MP10 & Gift song & Fast even & 123 \\
\hline 23 & MP10 (R) & Gift song & Fast even & 120 \\
\hline 24 & MP10 (R) & Gift song & Fast even & 120 \\
\hline 25 & MP11 & Bobo (K: farewell song) & Slow & 95 \\
\hline 26 & MP12 & 'Going down' & Fast-doubled & 200 \\
\hline 27 & MP12 (R) & 'Going down' & Fast-doubled & 198 \\
\hline 28 & MP13 & Man-me (K: tucker) & Fast even & 121 \\
\hline 29 & MP01 & Kiwken (M: boss song) & Fast even & 121 \\
\hline 30 & MP01 (R) & Kiwken (M: boss song) & Fast even & 121 \\
\hline
\end{tabular}

\section{Figure 6: Mirrijpu songs in performed order by Solomon Nangamu and Russell Agalara at Mikkinj Valley.}

Note: MP indicates a Mirrijpu song item, $(\mathrm{R})$ indicates a repeated song item and 'bpm' indicates 'beats per minute'. Recently conceived songs performed for the occasion are shaded grey. 


\section{Song Order and Spirit Intervention in Solomon Nangamu and Russell Agalara's Performance of Mirrijpu Songs}

The extent to which performances in funeral ceremonies are constructed in order to reflect these connections between the living and the deceased was revealed to me in discussions with Mirrijpu songmen Nangamu and Agalara about how they ordered the songs during the performance they gave the evening before the burial (see Figure 4). Generally speaking, there is no strict order to the performance of western Arnhem Land songs; song order varies from one performance to the next, depending on the occasion. Nevertheless, songmen make particular choices according to ceremonial precedents established by their ancestors, and according to the action taking place in their immediate environment. The effect is to produce a sequence of songs that is desirable both to their living audience (the mourners and dancers) and to their deceased audience (ancestral spirits listening in). ${ }^{69}$

In determining how a performance is put together, western Arnhem Land songmen consider the familiarity of a particular song for both the living and the deceased. Often, they use the English terms 'old' and 'new' to make the distinction between songs that have been passed down from korroko (K: before; a long time ago), and recent dream-conceived songs. Of course, the use of these terms can set up a false dichotomy since, from a Bininj perspective, all songs come from the same ancestral source, and 'new' songs are often attributed to the same relative who taught them the 'old' songs while they were alive. (This explains why songmen sometimes describe recently conceived songs as 'new, but old' or 'still the same one [as others in the song-set]'). On a musical level, 'new' songs usually share the same sung syllables (or song text), the same rhythmic modes and the same melodic units $^{70}$ as 'old' songs, but slightly re-arranged and varied, to give the impression of 'new, but old' ${ }^{71}$ One of Nangamu's reasons for attending the ceremony was out of respect for the important role that Nakodjok had played as a ceremony leader. Before the ceremony, he told me that he intended to perform three songs for the first time, including two songs (song items MP04 and MP10 in Figure 6) that had been given to him by the spirit of Nakodjok not long after the 'old man' had passed away. On a social level, the debut of these new songs on such an important occasion would have generated interest among Bininj who were already familiar with Mirrijpu songs, listening to the 'new' songs for the first time. On a political

69 This is consistent with Treloyn's observation of Kimberley performance, where the pairing of slow/fast songs which share subject matter and lexical content in Scotty Martin's junba repertory 'has the overall effect of foregrounding the relationship between the living performers, and the spirits ... that they enact on the dance ground'. Sally Treloyn, “'When Everybody There Together ... Then I Call That One": Song order in the Kimberley', Context 32 (2007): 110. See also Barwick's discussion of the pairing of slow and fast songs that are thematically linked in Marri Ngarr lirrga songs. Linda Barwick, 'Marri Ngarr Lirrga Songs: A musicological analysis of song pairs in performance', Musicology Australia 28 (2005): 13; Linda Barwick, 'Tempo Bands, Metre and Rhythmic Mode in Marri Ngarr "Church Lirrga" Songs', Australasian Music Research 7 (2002): 82. 70 See Treloyn, this volume.

71 For similar discussion in relation to north-east Arnhem Land song traditions, see Steven Knopoff, 'Yuta Manikay: Juxtaposition of ancestral and contemporary elements in the performance of Yolngu clan songs', Yearbook for Traditional Music 24 (1992): 138-53. 
level, as mentioned earlier, it would have further demonstrated the singer's affiliation with the song-set and the Country connected to it. Given this, one might expect Nangamu to have begun with one of these songs. Instead, following the precedents set down by his own Manangkardi ancestors, and in order to pay respect to the songmen before him, he performed first a number of old songs in the set, building up to the new material that he intended to sing for both his immediate audience and for Nakodjok himself (see Figure 6). Towards the end of the session, he returned once more to the songs from korroko, which would be more familiar to his ancestors.

A second consideration songmen make in ordering the songs is the "rhythmic mode' in which the song is performed. Rhythmic modes-defined as 'the intersection of tempo bands and clapstick-beating patterns ${ }^{72}$ - correspond to different dance styles across song repertories all over northern Australia. ${ }^{73}$ For example, many of the Mirrijpu songs performed that evening were in fast tempo band (120-125 beats per minute), named nulatparlangkat in Mawng. Nulatparlangkat songs feature men's dancing, and are performed in this instance either with 'even' beating of the clapsticks on the beat ('fast even' rhythmic mode) or 'doubled' beating ('fast-doubled' rhythmic mode, 240-260 beats per minute). Moderate (110-119 beats per minute) and slow (95-110 beats per minute) tempo bands - called nulatparlilil in Mawng-typically feature women's dancing. ${ }^{74}$ During 'instrumental sections' of the song (in between verses where the song text is sung), the clapstick beating usually changes to a gapped pattern - for example, MP06 has the gapped pattern $(\downarrow)$ in triple meter. This is when the bininj dancers stamp the ground with their feet, and pause with the gap in the clapstick beat.

Generally, Nangamu begins his performance with songs in 'moderate even' or 'fast even' rhythmic mode, and gradually increases the tempo through the performance, performing a spell of fast-doubled rhythmic mode songs in the middle section for the bininj dancers. As he did later that evening, Nangamu then returns to moderate and slow tempo songs toward the end of the performance, finishing with the 'mother' song (these songs were not recorded and are therefore not represented in Figure 6). Similarly, songmen 'follow the

\footnotetext{
72 Marett, Songs, Dreamings, and Ghosts, 204. Marett outlines a number of rhythmic modes used for wangga repertories, on which I base my own tempo bands for western Arnhem Land song repertories. A number of other factors such as the vocal and didjeridu rhythm also determine the rhythmic mode, but for reasons of scope, I concern my analysis here mainly with the tempo of the songs.

73 See Gregory D. Anderson, 'Striking a Balance: Limited variability in performances of a clan song series from Arnhem Land', in The Essence of Singing and the Substance of Song: Recent responses to the Aboriginal performing arts and other essays in honour of Catherine Ellis, eds Linda Barwick, Allan Marett and Guy Tunstill (Sydney: University of Sydney, 1995), 14-16.

74 Songs in all rhythmic modes can also be performed without dancing.
} 
track' of their ancestors by performing particular song items first in slow or moderate rhythmic modes before re-stating them in fast rhythmic mode (for example, song item MP06 in Figure 6).

So important is the consideration of tempo (along with the correct rhythm, and singing of the song text), that the songmen frequently repeat a song item and will not move on to the next one until they have performed it the 'right way' adjusting the tempo down slightly by two or three beats per minute until they feel they have got it right (see tempo for song items marked ' $\mathrm{R}$ ' for 'repeat' in Figure 6). Even after a long pause between songs, when Nangamu began to sing a new song item, the tempo frequently stayed the same-faster or slower within one or two beats per minute (see song numbers 20-24 and 28-30, Figure $6)$. Such accurate sense of tempo has been observed elsewhere among singers of Northern Australian Aboriginal song traditions. ${ }^{75}$

A further consideration for Nangamu is the way in which the performance environment calls for certain song items that he has assigned to particular categories or given particular associations. For example, a number of the songs he performed were what he calls bobo (or 'farewell') songs, which he 'brings out' for funeral ceremonies in particular (see songs 2-5, Figure 6). Song item MP11, for example, is a bobo song Nangamu performed at the funeral of his older brother in 2007; he explained to me that 'if one of my family passes away, I sing that song' ${ }^{76}$ Other associations given to song items included warramumpik (M: 'love songs', a reference to another sub-category of kun-borrk song-sets), songs that he associates with a spiritual return to his Country, expressed in English as 'going down' songs, and songs associated with all of the kinds of man-me (K: food or 'tucker') found at particular sites in his Country of north Goulburn Island. At times the choice to perform a song from one of these categories related what was going on around the singer, such as when Nangamu noticed people cooking their dinner on the fire, and returned to song item MP04, a man-me song (song number 13, Figure 6). Tellingly, the song Nangamu calls kiwken (M: boss) - MPO1 - features frequently here and in other recordings I have made of Mirrijpu songs, and is usually one that he opens his performance with and returns to throughout (here, he comes back to it midway through the performance and returns to it at the end). Finally, there is the ngaya (M: daughter $)^{77}$ song, which usually precedes the final nigi (M: mother) song. Later, in the early hours of the morning, Nangamu and Agalara sang the ngaya/nigi (daughter/mother) sequence to finish their performance.

75 For further discussion, see Freya Bailes and Linda Barwick, 'Absolute Tempo in Multiple Performances of Aboriginal Songs: Analyzing recordings of Djanba 12 and Djanba 14', Music Perception 28:5 (2011): 473-90.

76 Solomon Nangamu, personal communication, 25 November 2012.

77 Nangamu translated this term as 'daughter', however it can be used by a woman to refer to her sons or daughters. 
Further discussion with the singers revealed the extent to which the spirit world is understood as affecting the outcome of the performance. On one occasion (song number 16) Nangamu began singing one song item (MP08) and then unintentionally switched mid-song to another song item from korroko (MP09), before returning again to the first song item. At the completion of the song, all of the performers laughed at Nangamu's apparent disorientation, and in the discussion that followed, Nangamu remarked 'that spirit bin grab me by the throat and he changed my voice!' In another example of spirit intervention, Agalara attributed his musical ability to sing songs with Solomon from korroko that he had heard but not previously performed in ceremony, to the assistance of the spirit of his grandfather-Nangamu's brother - through whom he first learned to sing Mirrijpu: ${ }^{78}$

He connects me onto that group [of] songs [from korroko] what my granddad [sings] ... he connects to me, when he sings it's sort of like a computer goes in my brain and I twist my tongue and start singing with him.' ${ }^{79}$

Agalara's comments recall once more Marett's observation about the possibility of song to open up a space between the spirit and living worlds. Through song, ancestral and deceased spirits can not only influence song order, but also intervene in the middle of songs and lead the songman in the direction of another song, or take control of the functions of his voice, the same way that a computer gamer might control an avatar.

\footnotetext{
78 Agalara's mother's father (deceased) was Nangamu's older brother. Nangamu and his brothers learned the Mirrijpu songs from their father. Agalara and Nangamu refer to each other by the reciprocal kinship term mammam, which is used for one's mother's (classificatory) father or mother's father's sister and conversely, one's daughter's daughter or daughter's son. (In the kinship system of western Arnhem Land one's father's brothers are all considered 'father', and one's mother's sisters considered 'mother'.)

79 Agalara, Brown, and Nangamu, 'That Spirit Changed My Voice'.
} 


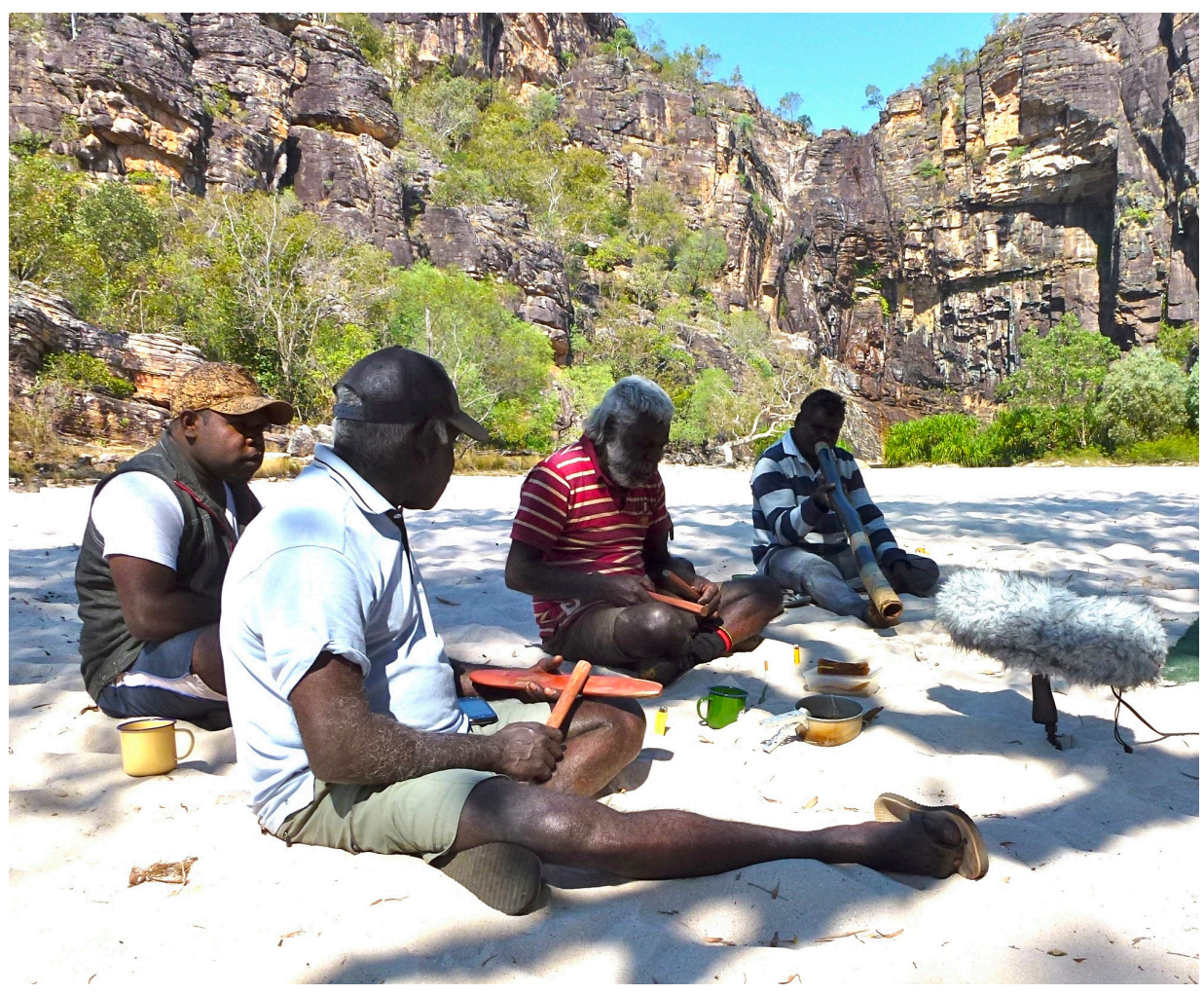

Figure 7: Singer Tommy Madjalkaidj (centre) performs Inyjalarrku songs near Gunbalanya. Russell Agalara (far left) and Alfred Gawaraidji (centre left) back up the singing, while Solomon Nangamu (right) accompanies on didjeridu.

Source: Photo by author.

\section{Conclusion}

Funeral ceremonies in western Arnhem Land continue to serve as the primary occasions in which relationships between different clan and cultural groups are acknowledged through ritual performance. The funeral ceremony for Nakodjok brought people from all over the region, who came to pay their respects and express their particular relationship with the deceased by performing their own song traditions. The diversity of music represented at this event points to the way songs express different linguistic, cultural and geographic identities and 
relationships. ${ }^{80}$ It also showed the importance of funerals in providing an event in which these connections and differences can be played out, and the region's rich song traditions can be maintained.

In many ways, Nakodjok's was a very contemporary funeral ceremony, with the incorporation of Christian rituals and non-Aboriginal music genres alongside Bininj mortuary rites and song traditions, and with the charter plane playing an essential role in transporting the body to and from regional and local morgues, as well as facilitating the participation of distant kin in the ceremony. At the same time, the focus of the ceremonial action was centred on the transition of the deceased spirit between the living and ancestral worlds (eventually carried home to its traditional Country through the performance of the 'mother' song). Kun-borrk song repertories and dances, with their access to the ancestral world and its language, are key to ensuring such transitions are managed, and are therefore vital to Bininj spirituality and the life cycle of the spirit.

Kun-borrk singers show their respect for their ongoing relationship with the ancestors, and for the songs they have inherited, in different ways. Firstly, by reserving the performance of these new songs for the occasion of the funeral ceremony, when spirits familiar to them (Agalara's grandfather, for example) and the spirit of the deceased (in this case, Nakodjok) are likely to hear their performance. And secondly, by endeavouring to perform the songs and dances handed down to them in a way that would have made previous songmen happy - setting the songs to particular rhythmic modes and matching the songs to the mood of the mourners around them in order to balance their emotions.

Importantly, these songs help Bininj not only to deal with death and say goodbye to their deceased relatives, but also to maintain some kind of relationship with them. For Agalara, the Mirrijpu songs he sings are his connection to his grandfather, and as long as he feels that his grandfather's spirit is with him, he will continue to perform the Mirrijpu songs at funeral ceremonies, and pass them on to the next generation: 'That relates to the family ... it doesn't matter where we go, the song is always there. ${ }^{81}$

\section{Acknowledgements}

Thanks to the Mawng and Kunwinjku songmen, in particular Solomon Nangamu, Russell Agalara, Alfred Gawaraidji, Tommy Madjalkaidj and Eric Mardday, and to the family of Nakodjok, including Connie and Alfred Nayinggul, for their contribution to this chapter. Thanks also to Bill Ivory and Donna Nadjamerrek

80 See Treloyn, this volume.

81 Agalara, Brown, and Nangamu, 'That Spirit Changed My Voice'. 
who assisted me during my stay in Gunbalanya and helped me to carry out my fieldwork. I am grateful to Ruth Singer for her help providing Mawng translations, as well as Linda Barwick, Amanda Harris and the two anonymous reviewers, for their generous feedback on this chapter.

\section{References}

Agalara, Russell, Reuben Brown, and Solomon Nangamu. 'That Spirit Changed My Voice: The performance of kun-borrk at a funeral ceremony in Mikkinj Valley, western Arnhem Land', Paper presented at the Musicological Society of Australia Annual Conference, The Australian National University, Canberra, 3-5 December 2012.

Anderson, Gregory D. 'Striking a Balance: Limited variability in performances of a clan song series from Arnhem Land', in The Essence of Singing and the Substance of Song: Recent responses to the Aboriginal performing arts and other essays in honour of Catherine Ellis, eds Linda Barwick, Allan Marett and Guy Tunstill (Sydney: University of Sydney, 1995), 13-25.

Apted, Meiki Elizabeth. 'Songs from the Inyjalarrku: The use of a nontranslatable spirit language in a song set from north-west Arnhem Land, Australia', Australian Journal of Linguistics 30:1 (2010): 93-103.

Barwick, Linda. 'Tempo Bands, Metre and Rhythmic Mode in Marri Ngarr “Church Lirrga" Songs', Australasian Music Research 7 (2002): 67-83.

Barwick, Linda. 'Marri Ngarr Lirrga Songs: A Musicological Analysis of Song Pairs in Performance', Musicology Australia 28 (2005): 1-25.

Barwick, Linda. 'Musical Form and Style in Murriny Patha Djanba Songs at Wadeye (Northern Territory, Australia)', in Analytical and Cross-Cultural Studies in World Music, eds Michael Tenzer and John Roeder (Oxford Scholarship Online: Oxford University Press, 2011), 317-51.

Bailes, Freya, and Linda Barwick. 'Absolute Tempo in Multiple Performances of Aboriginal Songs: Analyzing recordings of Djanba 12 and Djanba 14', Music Perception 28:5 (2011): 473-90.

Barwick, Linda, Bruce Birch, and Nicholas Evans. 'Iwaidja Jurtbirrk Songs: Bringing language and music together', Australian Aboriginal Studies 2 (2007): 6-34. 
Barwick, Linda, and Allan Marett. 'Snapshots of Musical Life: The 1948 recordings', in Exploring the Legacy of the 1948 Arnhem Land Expedition, eds Martin Thomas and Margo Neale (Canberra: ANU E Press, 2011), 355-77.

Berndt, Ronald M. 'Ceremonial Exchange in Western Arnhem Land', Southwestern Journal of Anthropology 7:2 (1951): 156-76.

Berndt, Ronald M. Australian Aboriginal Religion (Leiden: E. J. Brill, 1974).

Berndt, Ronald M. Love Songs of Arnhem Land (Melbourne: T. Nelson, 1976).

Brown, Reuben. Performance as Exchange: The role of western Arnhem Land song traditions in contemporary society ( $\mathrm{PhD}$, Conservatorium of Music, The University of Sydney, 2014 forthcoming).

Deger, Jennifer. 'Imprinting on the Heart: Photography and contemporary Yolngu mournings', Visual Anthropology 21 (2008): 292-309.

Evans, Nicholas. Bininj Gun-wok: A pan-dialectal grammar of Mayali, Kunwinjku and Kune. 2 volumes (Canberra: Pacific Linguistics, 2003).

Fitzgerald, Jon, and Philip Hayward. 'At the Confluence: Slim Dusty and Australian country music', in Outback and Urban: Australian country music, ed. Philip Hayward (Gympie: AICM Press, 2003), 29-54.

Garde, Murray. 'The Language of Kun-borrk in Western Arnhem Land', Musicology Australia 28 (2006): 59-89.

Garde, Murray. 'Nakodjok Namanilakarr', Bininj Gunwok (blog), 27 June 2012, http://bininjgunwok.org.au/blog/page/3/.

Glaskin, Katie, Myrna Tonkinson, Yasmine Musharbash, and Victoria Burbank, eds. Mortality, Mourning and Mortuary Practices in Indigenous Australia (Surrey: Ashgate, 2008).

Keen, Ian. Aboriginal Economy and Society: Australia at the threshold of colonisation (South Melbourne: Oxford University Press, 2004).

Knopoff, Steven. 'Yuta Manikay: Juxtaposition of ancestral and contemporary elements in the performance of Yolngu clan songs', Yearbook for Traditional Music 24 (1992): 138-53

Magowan, Fiona. Melodies of Mourning: Music and emotion in Northern Australia (Crawley: University of Western Australia Press, 2007).

Marrala, Khaki et al. Kindi Ngamin Nuwung? What Do I Call You? 'Ma!' Vol. 1, (Jabiru: Iwaidja Inyman, 2008). 
Marett, Allan. 'Ghostly Voices: Some observations on song-creation, ceremony and being in north western Australia', Oceania 71:1 (2000): 18-29.

Marett, Allan. Songs, Dreamings, and Ghosts: The wangga of north Australia (Middletown: Wesleyan University Press, 2005).

Marett, Allan, Linda Barwick, and Lysbeth Ford. For the Sake of a Song: Wangga songmen and their repertories: The Indigenous music of Australia, Book 2 (Sydney: Sydney University Press, 2013).

McKenzie, Kim. Waiting for Harry (Canberra: Australian Institute of Aboriginal Studies, 1980).

Morphy, Howard. Journey to the Crocodile's Nest: An accompanying monograph to the film Madarrpa funeral at Gurka'wuy (Canberra: Australian Institute of Aboriginal Studies, 1984).

Morphy, Howard, and Frances Morphy. 'Afterword: Demography and destiny', in Mortality, Mourning and Mortuary Practices in Indigenous Australia, eds Katie Glaskin, Myrna Tonkinson, Yasmine Musharbash and Victoria Burbank (Surrey: Ashgate, 2008), 209-15.

O'Keeffe, Isabel. 'Sung and Spoken: An analysis of two different versions of a Kun-Barlang love song', Australian Aboriginal Studies 2 (2007): 46-62.

O'Keeffe, Isabel. 'Kaddikkaddik Ka-Wokdjanganj "Kaddikkaddik Spoke": Language and music of the Kun-barlang Kaddikkaddik songs from western Arnhem Land', Australian Journal of Linguistics 30:1 (2010): 35-51.

Poignant, Roslyn, and Axel Poignant. Encounter at Nagalarramba (Canberra: National Library of Australia, 1996).

Reid, Janice. 'A Time to Live, a Time to Grieve: Patterns and processes of mourning among the Yolngu of Australia', Culture, Medicine and Psychiatry 3:4 (1979): 319-46.

Rose, Deborah B. Dingo Makes Us Human: Life and land in an Australian Aboriginal culture (Cambridge: Cambridge University Press, 2009).

Ross, Margaret Clunies, and Stephen A. Wild. 'Formal Performance: The relations of music, text and dance in Arnhem Land clan songs', Ethnomusicology 28:2 (1984): 209-35.

Spencer, Baldwin, Sir. Native Tribes of the Northern Territory of Australia (London: Macmillan, 1914). 
Singer, Ruth. Agreement in Mawng: Productive and lexicalised uses of agreement in an Australian language ( $\mathrm{PhD}$, Department of Linguistics and Applied Linguistics, University of Melbourne, 2006).

Toner, P. G. 'Tropes of Longing and Belonging: Nostalgia and musical instruments in northeast Arnhem Land', Yearbook for Traditional Music 37 (2005): 1-24.

Tonkinson, Myrna. 'Solidarity in Shared Loss: Death-related observances among the Martu of the Western Desert', in Mortality, Mourning and Mortuary Practices in Indigenous Australia, eds Katie Glaskin et al. (Surrey: Ashgate, 2008).

Treloyn, Sally. 'Scotty Martin's Jadmi Junba: A song series from the Kimberley region of northwest Australia', Oceania 73:3 (2003): 208-20.

Treloyn, Sally. "'When Everybody There Together ... Then I Call That One": Song order in the Kimberley', Context 32 (2007): 105-21.

Walker, Clinton. Buried Country: The story of Aboriginal country music (Sydney: Pluto Press, 2000).

Warner, Lloyd W. A Black Civilization: A social study of an Australian tribe (Gloucester: P. Smith, 1969). 
This text taken from Circulating Cultures: Exchanges of Australian Indigenous music, dance and media, edited by Amanda Harris, published 2014 by ANU Press, The Australian National University, Canberra, Australia. 